\title{
Blood group and protein polymorphism in the Finnish native cattle populations
}

\author{
Juha Kantanen and Matti OJala
}

\begin{abstract}
KANTANEN, J. \& OJALA, M. 1994. Blood group and protein polymorphism in the Finnish native cattle populations. Agricultural Science in Finland 3: 169-176. (Department of Animal Science, P.O. Box 28, FIN-00014 University of Helsinki, Finland. Present address: Juha Kantanen, Agricultural Research Centre of Finland, Institute of Animal Production, FIN-31600 Jokioinen, Finland.)
\end{abstract}

\begin{abstract}
Nine blood group loci and five polymorphic protein loci were investigated in the native East-, North- and West-Finnish cattle populations. The studied East-, Northand West-Finnish cattle populations comprised 74, 55 and 121 individuals, respectively. According to the average degree of heterozygosity, East-Finnish cattle had the highest genetic variation and North-Finnish cattle the lowest. Within the loci investigated, the East- and North-Finnish cattle populations, which are threatened by extinction, did not lack genetic diversity. The genetic distances between Westand North-Finnish cattle calculated by the NEI's (1972) standard method ranged from 0.019 to 0.052 in three partly different locus groups and between East- and North-Finnish cattle from 0.034 to 0.046 . The distances between East- and WestFinnish cattle were 0.030 in all cases. According to these results, East-, West- and North-Finnish cattle could be regarded as three different native breeds.
\end{abstract}

Key words: local cattle breed, heterozygosity, genetic distance

\section{Introduction}

The Finnish native cattle populations were named on the basis of their geographic breeding areas. East-Finnish cattle $(\mathrm{EFc})$ are usually brown-sided. North-Finnish cattle $(\mathrm{NFc})$ are white with brown or black spots and West-Finnish cattle $(\mathrm{WFc})$ are brown. Indigenous cattle are almost exclusively polled. At the beginning of this century there were three native cattle herd book societies in Finland. Since the fusion of the societies in 1947, the populations were regarded as one population and breed, Finncattle.

The number of Finnish native cows has declined drastically. Still in 1970 there were 307 600 Finncattle, but in 1980 their number had dropped to 42800 and in 1991 down to only
7900 , which is $1.6 \%$ of the total dairy cattle population in Finland. West-Finnish cattle are the largest group -7700 out of the total 7900 . The $\mathrm{EFc}$ and $\mathrm{NFc}$ populations, with 70 and 60 purebred cows left, respectively, can be regarded as threatened by extinction. The indigenous cattle have been replaced by Finnish Ayrshire (FAy) and Finnish Friesian (FFr).

The polymorphic character of genetically determined red ceil antigens and blood protein systems, and their simple mode of inheritance make them valuable for studying the origin, structure and relationship of breeds. Blood polymorphism can also be utilized as a measure of genetic variation. This study was conducted to determine the alleles or the phenogroups of the blood groups and blood protein systems in the Finnish native 
cattle populations, to investigate the average degree of heterozygosity and to calculate the genetic distances between East-, North- and West-Finnish cattle.

\section{Material and methods}

Blood samples were collected from a total of 250 native cattle (Table 1). The animals belonged to 43 herds located in different parts of Finland. For comparison, 50 Finnish Ayrshire (FAy) and 50 Finnish Friesian (FFr) animals were tested as well. The number of sires of the sampled animals were estimated to be between 22 and 37 in EFc, between 16 and 18 in NFc and 50 in WFc. Of these, $7 \mathrm{EFc}, 10 \mathrm{NFc}$ and $48 \mathrm{WFc}$ males had been used in artificial insemination (AI) and the rest of the bulls only in their birth herds. East-, North- and West-Finnish cattle AI bulls had on an average 3.7, 4.3 and 2.4 progenies, respectively. Both FAy and FFr animals had been sired by 50 AI bulls. The sires of all the studied populations were not included in the present material.

Blood samples were typed for nine red cell antigen and five polymorphic protein systems (Table 2). The variants in the five blood plasma protein systems were determined by horizontal and two-dimensional polyacrylamide gel electrophoresis. The technique employed in blood group tests and electrophoresis has been described by BRAEND (1959), GAHNE et al. (1977) and JUNEJA and GAHNE (1980).

Table 1. Number of tested animals.

\begin{tabular}{lcrrrr}
\hline & \multicolumn{5}{c}{ POPULATIONS } \\
& EFc & NFc & WFc & FAy & FFr \\
\hline Female & 52 & 37 & 117 & 47 & 45 \\
Male & 22 & 18 & 4 & 3 & 5 \\
Total & 74 & 55 & 121 & 50 & 50 \\
\hline
\end{tabular}

Populations:

$\mathrm{EFc}=$ East-Finnish cattle

NFc $=$ North-Finnish cattle

WFc $=$ West-Finnish cattle

FAy $=$ Finnish Ayrshire

$\mathrm{FFr}=$ Finnish Friesian
Table 2. Symbols for the blood group and protein systems tested and, in parentheses, the factors and variants within each system.

\section{BLOOD GROUP SYSTEMS}

A $(A, H)$

B (B,G,K, I, $\mathrm{I}_{2}, \mathrm{O}_{1}, \mathrm{O}_{3}, \mathrm{O}_{x}, \mathrm{P}, \mathrm{Q}, \mathrm{T}_{1}, \mathrm{~T}_{2}, \mathrm{Y}_{1}, \mathrm{Y}_{2}, \mathrm{~A}_{2}{ }_{2}, \mathrm{~B}$ ', B', D', E' $\left.{ }_{2}, \mathrm{E}_{3}^{\prime}, \mathrm{G}^{\prime}, \mathrm{I}^{\prime}, \mathrm{J}^{\prime} \mathrm{K}^{\prime}, \mathrm{O}^{\prime}, \mathrm{P}^{\prime}, \mathrm{Y}^{\prime}, \mathrm{F}^{\prime}{ }_{1}\right)$

$\mathrm{F}(\mathrm{F}, \mathrm{V})$

$\mathrm{J}(\mathrm{J})$

$\mathrm{L}(\mathrm{L})$

$\mathrm{M}(\mathrm{M})$

$\mathrm{Z}(\mathrm{Z})$

$\mathrm{R}^{\prime}\left(\mathrm{R}^{\prime}, \mathrm{S}^{\prime}\right)$

T'(T')

\section{BLOOD PROTEIN SYSTEMS}

\begin{tabular}{ll} 
Pa & (Post-albumin F and S) \\
Tf & (Transferrin A, D and E) \\
Ptf 1 & (Post-transferrin 1 A and B) \\
Ptf 2 & (Post-transferrin 2 F and S) \\
Pi-2 & $\left(\alpha_{1}\right.$-protease inhibitor F, I and S) \\
\hline
\end{tabular}

The term allele is used in this report instead of a factor or a variant, except in the B blood group system where the terms B factor and B phenogroup are employed. The presence of a factor, e.g. G, means that the animal reacts positively with the reagent for G. A phenogroup stands for a combination of factors which is inherited as a block, e.g. $\mathrm{BGO}_{1}$.

The F and R' blood groups and the investigated protein systems form so-called closed systems, where an individual's genotype can be directly determined in a laboratory test. Other blood group systems are open systems where an individual's genotype may be deduced from its parents' or progeny's phenotypes. Thus, in the closed systems the alleles are codominant, whereas dominance is present in the open systems. Depending on the nature of the system, the allele frequencies were estimated by different counting methods (FALCONER 1981). In the B system the frequencies of the phenogroups were estimated with BRAEND's (1963) square root method.

East- and West-Finnish cattle were divided into two groups according to the geographic location 
of the herd. There were $30 \mathrm{EFc}$ and $40 \mathrm{WFc}$ animals in South and Central Finland (region 1) and $44 \mathrm{EFc}$ and $81 \mathrm{WFc}$ animals in North Finland (region 2). In the EFc population there were four genetically isolated herds, which had 4, 6, 14 and 15 animals, a total of 39 animals. Inbreeding has obviously occurred in these herds, each of which formed a closed mating unit for over five cattle generations. The existence of genetic equilibrium and the regional and isolational effects were studied using of the codominant systems. The average degree of heterozygosity of the closed systems was estimated according to FERGUSON (1980). There were no half- or fullsibs or parent-progeny pairs in the calculations. The $\chi^{2}$ independence test was employed to calculate the statistical significance for the differences between the populations in the allele frequencies of the closed systems and for investigating the genetic equilibrium as well as the regional and isolational effects.

Genetic distances among EFc, NFc and WFc and among WFc, FAy and FFr were estimated according to NEI's (1972) standard method. Three locus groups were used in the calculation. The first locus group included the $\mathrm{F}$ and $\mathrm{R}$ ' blood groups and the $\mathrm{Pa}, \mathrm{Tf}, \mathrm{Ptf} 1, \mathrm{Ptf} 2$ and $\mathrm{Pi}-2$ protein systems, the second group the A, B, J, L, M, $\mathrm{Z}$ and $\mathrm{T}$ ' blood groups and the third group the closed and the open systems together.

\section{Results}

\section{Allele and genotype frequencies}

Statistically significant differences $(\mathrm{p}<0.001)$ were found between $\mathrm{EFc}, \mathrm{NFc}$ and $\mathrm{WFc}$ in the allele frequencies of the F, Pa, Tf, Ptf 2 and Pi-2 systems (Table 3). The $\mathrm{Pa}^{\mathrm{F}}$ allele of postalbumin in the EFc population was more than twice or three times as numerous as in WFc or in NFc, respectively. The $\mathrm{Tf}^{\mathrm{D}}$ was the most frequent allele of the transferrin system in NFc and WFc, but not in $\mathrm{EFc}$, in which the $\mathrm{Tf}^{\mathrm{A}}$ allele had the highest frequency. The presence of the $\mathrm{Tf}^{\mathrm{E}}$ and the $\mathrm{Ptf} 2^{\mathrm{S}}$
Table 3. Allele frequencies in East-, North- and WestFinnish cattle.

\begin{tabular}{|c|c|c|c|c|}
\hline \multicolumn{5}{|c|}{ CLOSED SYSTEMS } \\
\hline Allele & $\mathrm{EFc}$ & $\mathrm{NFc}$ & WFc & $\begin{array}{c}\text { Level of } \\
\text { significance }\end{array}$ \\
\hline $\mathrm{N}$ & 74 & 55 & 121 & \\
\hline $\mathrm{F}^{\mathrm{F}}$ & 0.966 ) & 0.763 ) & 0.673 ) & \multirow[b]{2}{*}{$* * *$} \\
\hline $\mathrm{F}^{\mathrm{V}}$ & $0.034\}$ & $0.237\}$ & $0.327\}$ & \\
\hline $\mathrm{R}^{\prime \mathrm{R}^{\prime}}$ & 0.027 & -1 & $0.004)$ & \multirow[b]{2}{*}{ N.S. } \\
\hline $\mathrm{R}^{\prime} \mathrm{s}^{\prime}$ & 0.973 & $1.000\}$ & 0.996 & \\
\hline $\mathrm{Pa}^{\mathrm{F}}$ & 0.250 & 0.073 & 0.107 ) & \multirow{2}{*}{$* * *$} \\
\hline $\mathrm{Pa}^{5}$ & $0.750 \mathrm{~J}$ & $0.927\}$ & 0.893 J & \\
\hline $\mathrm{Tf}^{\mathrm{A}}$ & $0.520)$ & $0.227)$ & $0.380)$ & \multirow{3}{*}{$* * *$} \\
\hline $\mathrm{Tf}^{\mathrm{D}}$ & $0.419\}$ & $0.555\}$ & $0.566\}$ & \\
\hline $\mathrm{Tf}^{\mathrm{E}}$ & $0.061 J$ & $0.218 J$ & $0.054 J$ & \\
\hline Ptf $1^{A}$ & 0.534 & 0.518 & $0.455\}$ & \multirow{2}{*}{ N.S. } \\
\hline $\mathrm{Ptf} 1^{\mathrm{B}}$ & $0.466\}$ & $0.482\}$ & $0.545\}$ & \\
\hline Ptf $2^{F}$ & 0.973 & 0.746 & 0.979 \} & \multirow{2}{*}{$* * *$} \\
\hline $\mathrm{Ptf} 2^{\mathrm{s}}$ & 0.027 J & $0.254\}$ & $0.021\}$ & \\
\hline $\mathrm{Pi}-2^{\mathrm{F}}$ & 0.095 & -1 & 0.045 ) & \multirow{3}{*}{$* * *$} \\
\hline $\mathrm{Pi}-2^{1}$ & $0.128\}$ & 0.009 & $0.033\}$ & \\
\hline$\underline{\mathrm{Pi}-2^{\mathrm{s}}}$ & 0.777 J & $0.991)$ & $0.922 J$ & \\
\hline \multicolumn{5}{|c|}{ OPEN SYSTEMS } \\
\hline $\mathrm{A}^{\mathrm{a}}$ & $0.647)$ & 0.603 ) & 0.575 ) & \\
\hline $\mathrm{A}^{\mathrm{A}}$ & $0.283\}$ & $0.249\}$ & $0.361\}$ & \\
\hline $\mathrm{A}^{\mathrm{AH}}$ & 0.070 J & 0.148 & 0.064 J & \\
\hline $\mathbf{J}^{\mathbf{J}}$ & 0.293 & 0.086 & $0.384\}$ & \\
\hline $\mathbf{J}^{\mathrm{j}}$ & $0.707\}$ & $0.914\}$ & $0.616\}$ & \\
\hline $\mathrm{L}^{\mathrm{L}}$ & 0.186 & 0.214 & $0.278\}$ & \\
\hline $\mathrm{L}^{\prime}$ & $0.814\}$ & $0.786\}$ & $0.722\}$ & \\
\hline $\mathbf{M}^{\mathrm{M}}$ & -1 & $0.064\}$ & $0.056\}$ & \\
\hline $\mathbf{M}^{\mathrm{m}}$ & $1.000\}$ & $0.936]$ & $0.944\}$ & \\
\hline$T^{\prime T}$ & 0.041 & 0.047 & 0.109 & \\
\hline$T^{\prime \prime \prime}$ & 0.959 ] & $0.953\}$ & $0.891\}$ & \\
\hline $\mathrm{Z}^{\mathrm{Z}}$ & 0.312 & 0.214 & $0.213\}$ & \\
\hline $\mathbf{Z}^{2}$ & 0.688 & 0.786 & 0.787 J & \\
\hline
\end{tabular}

$\mathrm{N} \quad=$ number of animals

$\mathrm{EFc}=$ East-Finnish cattle

NFc $=$ North-Finnish cattle

WFc $=$ West-Finnish cattle

Level of statistical significance between the allele frequencies in $\mathrm{EFc}, \mathrm{NFc}$ and $\mathrm{WFc}$ :

$* * *=p<0.001$, N.S.=non-significant

is conspicuously high $(0.218$ and 0.254$)$ in the NFc population in comparison to the other populations. East-Finnish cattle had a comparatively high frequency of the $\mathrm{Pi}-2^{1}$ allele in the $\alpha_{1}$-protease inhibitor system. 
West-Finnish cattle were in genetic equilibrium in all of the seven studied closed systems, but East-Finnish in six and North-Finnish only in five systems. For the Tf system there was a significant difference $(\mathrm{p}<0.05)$ between the observed and expected genotype frequencies for genetic equilibrium in $\mathrm{EFc}$, while in NFc significant differences $(\mathrm{p}<0.05)$ were found in the $\mathrm{F}$ blood group and the Ptf 1 systems.

The most frequent $\mathrm{A}$ allele was $\mathrm{A}^{\mathrm{a}}$ (Table 3). The $\mathrm{A}^{\mathrm{AH}}$ allele was more common in NFc than in the other populations. The $\mathrm{J}^{\mathrm{j}}, \mathrm{L}^{\mathrm{I}}, \mathrm{M}^{\mathrm{m}}, \mathrm{T}^{\prime \mathrm{t}^{\prime}}$ and $\mathrm{Z}^{\mathrm{z}}$ alleles had the highest frequencies in all populations. $\mathrm{EFc}$ was monomorphic in the $\mathrm{M}$ blood group system. The $\mathrm{T}^{\text {' }}{ }^{\prime}$ was over twice as numerous in WFc as in the other populations.

\section{The phenogroups in blood group system B}

The number of $\mathrm{B}$ factors in the EFc, NFc and WFc populations was 23,17 and 25 , respectively. The determination of the B phenogroups was based on the blood types of available parent-offspring pairs and the characteristic association of the B factors. There were 128 animals in which both B phenogroups were determinable. In 82 animals only one of the two B phenogroups could be determined, and no B phenogroups could be recognized in 40 animals. A total of 16,15 and 27 different phenogroups were discovered in East-, North- and West-Finnish cattle, respectively (Table 4), which indicates a rather high degree of variation.

The most frequent B phenogroups in East-Finnish cattle were the recessive $b(0.216), I_{1}(0.170)$, $\mathrm{O}_{1}(0.091)$ and $\mathrm{A}_{2}{ }_{2} \mathrm{E}_{3} \mathrm{G}^{\prime}(0.091)$, whereas in NorthFinnish cattle $\mathrm{O}_{1} \mathrm{~A}_{2}^{\prime}(0.355), \mathrm{O}_{1} \mathrm{E}_{2}^{\prime}(0.183)$, $\mathrm{Y}_{2} \mathrm{E}_{2} \mathrm{G}^{\prime}$ (0.086) and GO T $\mathrm{D}_{2} \mathrm{G}^{\prime}(0.075)$ were most common. There were no $\mathrm{O}_{1} \mathrm{~A}_{2}$-homozygotes among the NFc animals for which both B phenogroups were determinable. The phenogroups with the highest frequencies in WFc were $\mathrm{GO}_{1} \mathrm{Y}_{2}$, $\mathrm{Y}_{2} \mathrm{D}^{\prime} \mathrm{G}^{\prime}, \mathrm{A}_{2}^{\prime}, \mathrm{I}_{2}$ and $\mathrm{BGO}_{1}$. East- and North-Finnish cattle did not have $\mathrm{Y}_{2} \mathrm{D}^{\prime} \mathrm{G}^{\prime}$ and $\mathrm{BGO}_{1}$. EastFinnish cattle also lacked $\mathrm{A}_{2}$. Only five phenogroups $\left(\mathrm{GO}_{1}, \mathrm{GO}_{1} \mathrm{Y}_{2}, \mathrm{I}_{2}, \mathrm{O}_{1} \mathrm{Y}_{2}\right.$ and I') were shared by all the three native breeds.
Table 4. Estimates of frequencies for phenogroups in blood group B.

\begin{tabular}{|c|c|c|c|}
\hline Phenogroup & $\mathrm{EFc}$ & $\mathrm{NFc}$ & WFc \\
\hline$\underline{\mathrm{N}}$ & 56 & 55 & 99 \\
\hline b & 0.216 & 0.032 & - \\
\hline BGKE' $_{2}$ & - & 0.064 & 0.057 \\
\hline $\mathrm{BGO}_{1}$ & - & - & 0.089 \\
\hline $\mathrm{BI}_{1}$ & - & - & 0.051 \\
\hline $\mathrm{BY}_{2} \mathrm{P}^{\prime} \mathrm{Y}^{\prime}$ & 0.068 & - & - \\
\hline $\mathrm{GO}_{1}$ & 0.079 & 0.011 & 0.013 \\
\hline $\mathrm{GO}_{1} \mathrm{Y}_{2}$ & 0.023 & 0.021 & 0.153 \\
\hline $\mathrm{GO}_{1} \mathrm{~T}_{2} \mathrm{D}^{\prime} \mathrm{G}^{\prime}$ & - & 0.075 & 0.013 \\
\hline $\mathrm{I}_{1}$ & 0.170 & - & 0.032 \\
\hline $\mathrm{I}_{2}$ & 0.023 & 0.043 & 0.102 \\
\hline $\mathrm{O}_{1}$ & 0.091 & - & - \\
\hline $\mathrm{O}_{1} \mathrm{~A}_{2}$ & 0.034 & 0.355 & - \\
\hline $\mathrm{O}_{1} \mathrm{~A}_{2}^{\prime 2} \mathrm{~B}^{\prime}$ & - & 0.021 & - \\
\hline $\mathrm{O}_{1} \mathrm{E}_{2}^{\prime}$ & - & 0.183 & - \\
\hline $\mathrm{O}_{1} \mathrm{E}_{2}^{\prime} \mathrm{G}^{\prime}$ & 0.045 & - & - \\
\hline $\mathrm{O}_{x} \mathrm{~A}_{2}$ & - & - & 0.047 \\
\hline $\mathrm{Y}_{2} \mathrm{D}^{\prime} \mathrm{G}^{\prime}$ & - & - & 0.134 \\
\hline $\mathrm{Y}_{2}^{2} \mathrm{E}_{2}^{\prime} \mathrm{G}^{\prime}$ & - & 0.086 & - \\
\hline $\mathrm{A}_{2}^{\prime}$ & - & 0.011 & 0.134 \\
\hline$A^{\prime}, E_{2}^{\prime} G^{\prime}$ & 0.091 & - & - \\
\hline D'G'I' & 0.045 & - & - \\
\hline$I^{\prime}$ & 0.023 & 0.054 & 0.013 \\
\hline Other groups & 0.091 & 0.043 & 0.162 \\
\hline Total & 0.999 & 0.999 & 1.000 \\
\hline
\end{tabular}

$\mathrm{N} \quad=$ number of animals

$\mathrm{EFc}=$ East-Finnish cattle

$\mathrm{NFc}=$ North-Finnish cattle

$\mathrm{WFc}=$ West-Finnish cattle

\section{Regional and isolation effects}

The regional differencies in the allele frequencies in East-Finnish cattle were significant in the $\mathrm{Pa} \quad(\mathrm{p}<0.001)$ and in the $\mathrm{Tf}(\mathrm{p}<0.05)$ systems (Table 5). The $\mathrm{F}^{\mathrm{V}}$ allele was not observed in the $\mathrm{EFc}$ population in region 2 . The differences in the allele frequencies between the two regional WFc populations were not statistically significant in any of the seven loci.

There were two isolated $\mathrm{EFc}$ herds in region 1 and also two herds in region 2. The allele frequencies in the isolated herds and in the nonisolated herds using AI deviated significantly $(\mathrm{p}<0.01)$ only in the Pi-2 locus (Table 6). With 
Table 5. Allele frequencies of the closed systems of East- and West-Finnish cattle in regions 1 and 2.

\begin{tabular}{lcccc}
\hline Allele & $\begin{array}{c}\mathrm{EFc} \\
\text { Region 1 }\end{array}$ & $\begin{array}{c}\text { EFc } \\
\text { Region 2 }\end{array}$ & $\begin{array}{c}\text { WFc } \\
\text { Region 1 }\end{array}$ & $\begin{array}{c}\text { WFc } \\
\text { Region 2 }\end{array}$ \\
\hline $\mathrm{N}$ & 30 & 44 & 40 & 81 \\
\hline $\mathrm{F}^{\mathrm{F}}$ & 0.916 & 1.0 & 0.613 & 0.704 \\
$\mathrm{~F}^{\mathrm{V}}$ & 0.084 & - & 0.387 & 0.296 \\
$\mathrm{R}^{\prime} \mathrm{R}^{\cdot}$ & 0.050 & 0.012 & - & 0.006 \\
$\mathrm{R}^{\prime}$ & 0.950 & 0.988 & 1.0 & 0.994 \\
$\mathrm{~Pa}^{\mathrm{F}}$ & 0.067 & 0.375 & 0.138 & 0.093 \\
$\mathrm{~Pa}^{\mathrm{S}}$ & 0.933 & 0.625 & 0.862 & 0.907 \\
$\mathrm{Tf}^{\wedge}$ & 0.166 & 0.761 & 0.438 & 0.352 \\
$\mathrm{Tf}^{\mathrm{D}}$ & 0.717 & 0.205 & 0.537 & 0.580 \\
$\mathrm{Tf}$ & 0.117 & 0.034 & 0.025 & 0.068 \\
$\mathrm{Ptf}^{\mathrm{E}} 1^{\wedge}$ & 0.633 & 0.466 & 0.425 & 0.469 \\
$\mathrm{Ptf} 1^{\mathrm{B}}$ & 0.367 & 0.534 & 0.575 & 0.531 \\
$\mathrm{Ptf} 2^{\mathrm{F}}$ & 0.983 & 0.966 & 0.962 & 0.988 \\
$\mathrm{Ptf}^{\mathrm{F}}$ & 0.017 & 0.034 & 0.038 & 0.012 \\
$\mathrm{Pi}-2^{\mathrm{F}}$ & 0.133 & 0.068 & 0.050 & 0.043 \\
$\mathrm{Pi}-2^{1}$ & 0.167 & 0.102 & 0.037 & 0.031 \\
$\mathrm{Pi}^{\mathrm{S}}$ & 0.700 & 0.830 & 0.913 & 0.926 \\
\hline
\end{tabular}

$\mathrm{N} \quad=$ number of animals

$\mathrm{EFc} \quad=$ East-Finnish cattle

WFc $\quad=$ West-Finnish cattle

Region 1 = South and Central Finland

Region 2 = North Finland

Table 6. Effect of isolation on the allele frequencies of the closed systems in East-Finnish cattle.

\begin{tabular}{|c|c|c|}
\hline Allele & Isol. herds & AI-herds \\
\hline $\mathrm{N}$ & 39 & 35 \\
\hline $\mathrm{F}^{\mathrm{F}}$ & 0.936 & 1.0 \\
\hline $\mathrm{F}^{\mathrm{v}}$ & 0.064 & - \\
\hline $\mathrm{R}^{\prime \mathrm{R}^{\prime}}$ & - & 0.057 \\
\hline $\mathbf{R}^{\prime s^{\prime}}$ & 1.0 & 0.943 \\
\hline $\mathrm{Pa}^{\mathrm{F}}$ & 0.244 & 0.257 \\
\hline $\mathrm{Pa}^{\mathrm{s}}$ & 0.756 & 0.743 \\
\hline $\mathrm{Tf}^{\wedge}$ & 0.474 & 0.572 \\
\hline $\mathrm{Tf}^{\mathrm{B}}$ & 0.462 & 0.371 \\
\hline $\mathrm{Tf}^{\mathrm{E}}$ & 0.064 & 0.057 \\
\hline Ptf $1^{\wedge}$ & 0.603 & 0.457 \\
\hline Ptf $1^{B}$ & 0.397 & 0.543 \\
\hline Ptf $2^{F}$ & 1.0 & 0.943 \\
\hline Ptf $2^{s}$ & - & 0.057 \\
\hline $\mathrm{Pi}-2^{\mathrm{F}}$ & 0.115 & 0.071 \\
\hline $\mathrm{Pi}-2^{1}$ & 0.039 & 0.229 \\
\hline $\mathrm{Pi}-2^{\mathrm{s}}$ & 0.846 & 0.700 \\
\hline
\end{tabular}

$\mathrm{N} \quad=$ number of animals

Isol. herds $=$ isolated herds having used bulls of their own.

AI-herds $=$ herds having used AI-bulls the exception of the F blood group there were less heterozygotic animals in the isolated herds than in other herds in all loci. Five B phenogroups - $\mathrm{I}_{1}, \mathrm{~A}_{2} \mathrm{E}_{3}{ }_{3} \mathrm{G}^{\prime}, \mathrm{GO}_{1} \mathrm{Y}_{2}$, D'G'I' and I' were frequent in the genetically isolated $\mathrm{EFc}$ herds.

\section{Degree of heterozygosity and genetic distances}

The average degree of heterozygosity $(\mathrm{H})$ was highest in East-Finnish cattle and lowest in NorthFinnish cattle (Table 7). NFc was monomorphic in the R' blood group and this locus was least diverse also in WFc. NFc had little variation in the Pi-2 although this locus has three alleles. With respect to the level of genetic variation in the loci of the closed systems, WFc and NFc were more similar than WFc and EFc. East- and NorthFinnish cattle differed the most.

West- and North-Finnish cattle were genetically most similar on the basis of the genetic dis- 
Table 7. Degree of heterozygosity $(\%)$ in the loci of the closed systems.

\begin{tabular}{lcrr}
\hline Locus & EFc & NFc & WFc \\
\hline $\mathrm{N}$ & 21 & 15 & 50 \\
\hline $\mathrm{F}$ & 13.19 & 27.82 & 46.08 \\
$\mathrm{R}$ & 13.19 & 0.00 & 1.98 \\
$\mathrm{~Pa}$ & 36.27 & 18.00 & 21.12 \\
Tf & 58.04 & 53.13 & 55.04 \\
Ptf 1 & 48.99 & 49.78 & 47.12 \\
Ptf 2 & 4.68 & 27.82 & 3.92 \\
Pi-2 & 44.93 & 6.38 & 20.14 \\
\hline H & 31.33 & 26.13 & 27.91 \\
\hline
\end{tabular}

$\mathrm{N}=$ number of animals

$\mathrm{EFc}=$ East-Finnish cattle

$\mathrm{NFc}=$ North-Finnish cattle

$\mathrm{WFc}=$ West-Finnish cattle

$\mathrm{H}=$ average degree of heterozygosity

tance (D) of the closed systems (locus group 1) $(D=0.019)$ and East- and North-Finnish cattle the most different $(\mathrm{D}=0.046)$ (Table 8). The genetic distance among Finnish Ayrshire and Finnish Friesian $(\mathrm{D}=0.020)$ was about equal to or smaller than the distances between the native populations.

With locus groups 2 and $3, \mathrm{NFc}$ and WFc were genetically more different $(\mathrm{D}=0.052$ or 0.035$)$ than EFc and WFc. The genetic distances be- tween EFc and WFc (D=0.030) were the same in all cases.

\section{Discussion}

The present results of the allele frequencies of WFc were almost the same as the results of VASENIUS (1965), who studied allele frequencies for the transferrin locus in 313 Finncattle, and those of MAiJala and LindSTröm (1966), who studied blood group alleles in 540 West-Finnish bulls. No fixation or loss of alleles in available loci in the West-Finnish cattle population was found when comparing the present study to the investigations made in the 1960's. The B phenogroup $\mathrm{Y}_{2} \mathrm{D}^{\prime} \mathrm{G}$ ', typical of WFc in this study, had not been observed in other native cattle populations in the Nordic countries (MAJJALA and LINDSTRÖM 1966). BAKER and MANWELl (1980) reported that the $\mathrm{Tf}^{\mathrm{E}}$ is characteristic of breeds which had been developed in harsh environments. The results in this study agree with that hypothesis, since the $\mathrm{Tf}^{\mathrm{E}}$ was found in a high frequency in North-Finnish cattle, a population of Finnish Lapland.

$\mathrm{EFc}$ and NFc were not in genetic equilibrium in all loci. The small population sizes, genetic drift, isolation and an obvious inbreeding in the

Table 8. Genetic distances between the populations on the basis of three locus groups.

\begin{tabular}{|c|c|c|c|c|c|c|c|c|}
\hline & \multicolumn{4}{|c|}{ LG 1} & \multicolumn{2}{|c|}{ LG 2} & \multicolumn{2}{|c|}{ LG 3} \\
\hline & FAy & FFr & $\mathrm{EFc}$ & $\mathrm{NFc}$ & $\mathrm{EFc}$ & $\mathrm{NFc}$ & $\mathrm{EFc}$ & $\mathrm{NFc}$ \\
\hline $\mathrm{EFc}$ & & & & 0.046 & & 0.034 & & 0.040 \\
\hline WFc & 0.034 & 0.025 & 0.030 & 0.019 & 0.030 & 0.052 & 0.030 & 0.035 \\
\hline FAy & & 0.020 & & & & & & \\
\hline
\end{tabular}

LG 1 = locus group 1

LG 2 = locus group 2

LG 3 = locus group 3

FAy $=$ Finnish Ayrshire

$\mathrm{FFr}=$ Finnish Friesian

$\mathrm{EFc}=$ East-Finnish cattle

NFc $=$ North-Finnish cattle

WFc $=$ West-Finnish cattle 
isolated $\mathrm{EFc}$ herds may be the major causes of a slight genetic disequilibrium.

YAMADA (1981) has suggested that an animal population could be subdivided into several lines for the preservation of genetic resources. This situation has partly developed in East-Finnish cattle. Line subdivision was less pronounced in NFc than in EFc or WFc. There were no full- or halfsibs among the WFc data used for the heterozygosity calculation. Some of the WFc animals were, however, related through their maternal or paternal grandsires. Only a few WFc bulls have so far been chosen to be employed in AI on a large scale. The magnitude of the heterozygosity observed in this study is important because it implies that East- and North-Finnish cattle may not, in fact, suffer from a lack of genetic variation.

Locus group 1 could be regarded to give the most reliable data for the calculation of the genetic distances, since the allele frequencies of the open systems were estimates only of the exact frequencies. West-Finnish cattle were genetically closer to Finnish Friesian than to Finnish Ayrshire although West-Finnish cattle and Ayrshire are both classified as belonging to the NorthEuropean cattle breedgroup according to BAKER and MANwell (1980). A share of WFc cows were crossbred with Ayrshire already in the 1950's and 1960 's, and with Friesian in the 1970's to upgrade the native cattle by these two breeds. Because of this, more genetic influence of WFc was left in FFr than in FAy. The genetic distances between the Finnish native cattle populations were nearly as great as, or greater than those between Finnish Ayrshire and Finnish Friesian. In a previous study among seven Spanish native cattle breeds, the genetic distances calculated by the NEI's (1972) standard method ranged from 0.007 to 0.180 (GonZales et al. 1987). The magnitude of the genetic distances among the Finnish native cattle populations $(0.019-0.046)$ relative to those between FAy and FFr and between Spanish native cattle breeds (GonZales et al. 1987) suggests that East-, North- and West-Finnish cattle are three different breeds and not only three different colour types of the same breed.

Several reasons may have caused the genetic differentiation of the Finnish native cattle breeds. Before the fusion of the three herd book societies in 1947, East-, North- and West-Finnish cattle were at least partly geographically isolated. Also the founding animals with which the breeding work of each native breed was begun may have been genetically different. The present East- and North-Finnish cattle breeds are only samples of the populations of past times. Genetic drift is obviously one of the major causes for differentiation. East-Finnish cattle have partly been isolated, and inbreeding in the isolated herds may have increased genetic differentiation in the $\mathrm{EFc}$ as opposed to the other native breeds.

Acknowledgements. The authors are grateful to Tirri Niini, Raili Huttunen, Kaarina Pirhonen and Ilona Salminen (The Blood Group Laboratory of the Finnish Animal Breeding Association) for the collaboration in testing blood samples.

\section{References}

Baker, C.M.A. \& Manwell, C. 1980. Chemical classification of cattle. 1. Breed groups. Animal Blood Groups and biochemical Genetics 11: 127-150.

BRAEND, M. 1959. Blood groups of cattle in Norway. 144 p. Skandinavisk Bladforlag, Oslo.

- 1963. Estimation of gene frequencies in the B-system of cattle. Immunogen. Letter 3: 43-48.

FALCONER, D.S. 1981. Introduction to quantitative genetics. 340 p. Longman Inc., New York.

FERGUSON, A. 1980. Biochemical systematics and evolution. 194 p. Blakkie and Son, Glasgow.

Gahne, B., Juneja, R.K. \& Grolmus, J. 1977. Horizontal polyacrylamide gradient gel electrophoresis for the simultaneous phenotyping of transferrin, post-transferrin, albumin and post-albumin in the blood plasma of cattle. Animal Blood Groups and biochemical Genetics 8: 127-137.

Gonzalez, P., Tuñon, M.J. \& Vallejo, M. 1987. Genetic relationship between seven Spanish native breeds of cattle. Animal Genetics 18: 249-256.

JUNEJA, R.K. \& GAHNE, B. 1980. Two-dimensional gel electrophoresis of cattle plasma proteins. Genetic polymorphism of an $\alpha 1$-protease inhibitor. Animal Blood Groups and biochemical Genetics 11: 215- 228. 
Maijala, K. \& Lindström, G. 1966. Frequencies of blood group genes and factors in the Finnish cattle breeds with special regard to breed comparisons. Annales Agriculturae Fenniae 5: 76-93.

NEI, M. 1972. Genetic distance between populations. American Naturalist 106: 283-292.

VASENIUS, L. 1965. Transferrin polymorphism in Finnish
Ayrshire cattle. Annales Academiae Scientiarum Fennicae Series A. IV. Biologica 98: 1-58.

YAMADA, Y. 1981. The importance of mating systems in the conservation of animal genetic resources. FAO Animal Production and Health Paper 24: 268-278.

Manuscript received October 1993

\title{
SELOSTUS
}

\section{Veriryhmä- ja veren valkuaisainepolymorfismi Suomen alkuperäisissä nautaroduissa}

\author{
Juha Kantanen ja Matti Ojala
}

Helsingin yliopisto

Suomalaisista alkuperäisistä nautapopulaatioista itä- ja pohjoissuomenkarja (ISK ja PSK) ovat kriittisesti uhanalaisia nautarotuja, sillä näissä populaatioissa on vain 70 ja 60 puhdasrotuista lisääntyvää naarasta. Länsisuomenkarjan (LSK) lehmiä on noin 8000 . Tutkimusaineisto koostui 74 ISK-, 121 LSK- ja 55 PSK-eläimen verinäytteistä. Suoritettujen vertailujen vuoksi analysoitiin 50 ayrshire- ja 50 friisiläisrodun eläintä. Alkuperäisrotujen geneettistä muuntelua ja geneettisiä etäisyyksiä tutkittiin yhdeksăn veriryhmä- ja viiden veren valkuaisainelokuksen perusteella. Veriryhmät määritettiin kansainvälistä hemolyyttistä testiä käyttäen. Naudan seerumiproteiinit tutkittiin yksi- tai kaksisuuntaisella polyakryyliamidi-elektroforeesilla. Rotujen geneettinen muuntelu arvioitiin seitsemän lokuksen heterotsygotia-asteiden keskiarvon perusteella. Geneettisten etäisyyksien laskennassa käytettiin kolmea lokusryhmää.

Geneettisesti muuntelevin rotu oli ISK. Vähiten muuntelua oli PSK:Ila. ISK ja PSK ovat pienestä populaatiokoostaan huolimatta geneettisesti muuntelevia populaatioita, kun verrataan näiden heterotsygotia-asteita LSK:n heterotsygotia-asteeseen. Suomalaisten alkuperäisrotujen geneettiset etäisyydet olivat lähes yhtä suuret tai suuremmat kuin ayrshiren ja friisiläisen välinen geneettinen etäisyys. Veriryhmä- ja valkuaisainelokusten polymorfian perusteella voitiin todeta, että itä-, länsi- ja pohjoissuomenkarja ovat kolme erillistä nautarotua. 